\title{
Utjecaj stupnja uglazbljenosti teksta na upamćivanje teksta
}

\author{
Augustin Mutak, Andrea Vranić \\ Odsjek za psihologiju, Filozofski fakultet Sveučilišta u Zagrebu, Hrvatska
}

\section{Sažetak}

Introspektivni nalazi pokazuju kako ljudi lakše i dulje pamte uglazbljeni materijal od drugih vrsta materijala. Sukladno tome, pokazuje se i da ljudi vjeruju da je glazba dobar mnemonik te da pomaže upamćivanju. Međutim, eksperimentalne provjere ne potvrđuju ove teze. U eksperimentima se pokazuje kako je pozitivan utjecaj glazbe na upamćivanje ovisan o uvjetima upamćivanja (npr. uglazbljen i neuglazbljen tekst pamte se jednako dobro ako je brzina prezentiranja riječi ista). Utjecaj stupnja uglazbljenosti materijala na njegovo upamćivanje vrlo se rijetko istražuje i stoga predstavlja predmet ovog istraživanja. Također, ovim je istraživanjem ispitano mijenjaju li se strategije upamćivanja materijala ovisno o stupnju njegove uglazbljenosti te mijenjaju li se karakteristike materijala na kojima se upamćivanje temelji ovisno o stupnju uglazbljenosti samog materijala.

U istraživanju je sudjelovao 91 sudionik. Sudionici su podijeljeni u tri skupine, a zadatak je svake skupine bio pokušati u što većoj mjeri upamtiti tekst skladbe. Pritom je prva skupina slušala a capella izvedbu, druga skupina vokalnu izvedbu praćenu bubnjevima, a treća potpuno uglazbljenu vokalnu izvedbu. Sudionici su slušali skladbu šest puta i nakon svakog slušanja zapisivali stihove koje su upamtili. Također, sudionici su ispunili i Upitnik o korištenim strategijama.

Analizom varijance nisu utvrđene razlike u broju upamćenih stihova između tri skupine sudionika koje su slušale materijal različitog stupnja uglazbljenosti. Također, nisu utvrđene razlike u čestini korištenja različitih strategija upamćivanja. Međutim, Fisherovim je egzaktnim testom utvrđen trend koji pokazuje da povećanjem stupnja uglazbljenosti teksta raste i broj sudionika koji izjavljuju da im pri upamćivanju pomaže glazba. Također, s povećanjem stupnja uglazbljenosti materijala smanjuje se broj osoba koje izjavljuju da im pri upamćivanju teksta pomaže priroda vokala.

Rezultati su ovog istraživanja sukladni s prethodnim nalazima koji sugeriraju da uglazbljenost objektivno ne pomaže pamćenju. No, čini se kako, neovisno o objektivnim pokazateljima, sudionici imaju dojam da im glazba pomaže u upamćivanju. Ova je mogućnost raspravljena kroz Kelleyjev kovarijacijski model atribucije. Predložene su dvije hipoteze za objašnjenje dobivenih rezultata: hipoteza o pogrešno percipiranoj visokoj distinktivnosti pamćenja glazbenog materijala i hipoteza o pogrešno percipiranoj visokoj konzistentnosti pamćenja glazbenog materijala.

Ključne riječi: dosjećanje, glazba, stupanj uglazbljenosti, mnemonik

Andrea Vranić, Odsjek za psihologiju, Filozofski fakultet Sveučilišta u Zagrebu, Ivana Lučića 3, 10000 Zagreb, Hrvatska. E-pošta: avranic@ffzg.hr 


\section{Uvod}

Glazba je dio svakodnevice suvremenoga čovjeka. Neovisno o tome inicira li osoba slušanje glazbe svojevoljno, pristane li na slušanje zbog društva ili joj slušanje bude nametnuto kroz televizijske reklame i druge vrste promidžbenih materijala, sigurno je da se čovjek danas vrlo često susreće s glazbom, čemu pomažu i suvremena tehnološka rješenja, poput prijenosnih reproduktora zvuka. Mnogo je glazbenih zapisa vokalno-instrumentalnog tipa što pogotovo vrijedi za velik broj skladbi koje se slušaju rekreativno.

Uvriježeno je mišljenje kako glazba pomaže upamćivanju. Introspektivni nalazi pokazuju kako ljudi lakše i dulje pamte uglazbljeni materijal od drugih vrsta materijala (Schulkind, 2009). Primjerice, smatra se kako je lakše zapamtiti tekst skladbe nego školsko gradivo ili vijesti iz politike. Spomenuta "preizloženost" glazbenom materijalu jedno je od mogućih objašnjenja percepcije boljeg pamćenja materijala praćenog glazbom. Naime, utvrđeno je kako se zaboravljanje smanjuje ako se informacije češće ponavljaju jer ponavljanje sprječava slabljenje traga $u$ pamćenju (Wickelgren, 1972). Drugim riječima, kako smo skladbama češće izloženi, odnosno kako se tekst unutar vokalne skladbe često ponavlja, vjerojatnost je upamćivanja tog teksta zbog čestine ponavljanja veća. Ovo potvrđuju već i rana istraživanja u području koja pokazuju da prenaučenost materijala dovodi do njegova duljeg zadržavanja (Krueger, 1929). Pri rekreativnom slušanju glazbe odabiremo onu glazbu koja nam se sviđa što također pojašnjava postojanje uvjerenja o glazbi kao dobrom mnemoniku jer istraživanja pokazuju kako se sadržaji koji nam se sviđaju bolje pamte od onih za koje ne pokazujemo preferencije (Rubin i Friendly, 1986; Thomson, 1930). U skladu s time, Stalinski i Schellenberg (2013) utvrđuju kako ljudi i bolje prepoznaju pjesme koje im se sviđaju od onih koje im se ne sviđaju.

Kulturalna su vjerovanja o posebnoj snazi glazbe kao mnemoniku vrlo raširena (Schulkind, 2009), o čemu govori i česta upotreba glazbe u mnogim primijenjenim područjima, npr. u marketingu. Tako Yalch (1991) utvrđuje kako ljudi bolje prepoznaju reklamne slogane ako su oni uglazbljeni. Premda malobrojna, znanstvena istraživanja utjecaja uglazbljenosti na pamćenje materijala postoje. Istraživanja pokazuju kako se ljudi bolje dosjećaju pjevanog od izgovaranog teksta (McElhinney i Annett, 1996; Wallace, 1994). Purnell-Webb i Speelman (2008) također navode kako uglazbljenost može pomoći pamćenju, ali samo ako je melodija poznata sudionicima. S druge strane, Kilgour, Jakobson i Cuddy (2000) pokazuju kako uglazbljenost nema utjecaja na pamćenje ako se brzina prezentiranja riječi u pjevanom i u govorenom tekstu izjednači, što dovodi u pitanje prethodno spomenute nalaze o pozitivnom utjecaju glazbe na pamćenje. 


\section{Učinkovitost glazbe kao mnemonika s obzirom na vrijeme retencije}

U dijelu preostalih istraživanja upamćivanja uglazbljenog materijala pamćenje je ispitivano neposredno nakon slušanja te nakon dužeg vremenskog perioda. Rezultati takvih istraživanja, uz kontrolu brzine prezentiranja obaju materijala, nisu jednoznačni. Neka istraživanja utvrđuju kako se neposredno pamćenje uglazbljenog i neuglazbljenog teksta ne razlikuje, već se razlika u pamćenju u korist uglazbljenog teksta iskazuje nakon tjedan dana (Gingold i Abravanel, 1987; Rainey i Larsen, 2002). Druga istraživanja ne utvrđuju razliku u upamćenosti uglazbljenog $i$ neuglazbljenog materijala ovisno o vremenu proteklom od slušanja materijala (Racette i Peretz, 2007). Zaključivanje o odnosu pamćenja uglazbljenog i neuglazbljenog materijala $\mathrm{s}$ obzirom na period retencije dodatno usložnjuje istraživanje Calverta i Tarta (1993) koje utvrđuje bolje upamćivanje uglazbljenog materijala, kako pri neposrednom, tako i pri odgođenom dosjećanju nakon pet tjedana.

Istraživanja koja eksperimentalno uspoređuju pamćenje uglazbljenog i neuglazbljenog materijala u vrlo dugim vremenskim periodima, poput godina i desetljeća, prema dostupnoj literaturi nisu provedena. Međutim, suprotno uvriježenom vjerovanju o glazbi kao mnemoniku toliko učinkovitom da sprječava zaboravljanje uglazbljenog materijala kroz čitav životni vijek, Schulkind, Hennis i Rubin (1999) utvrđuju drugačije rezultate. Oni su u svojem istraživanju mlađim (18 -21 godina) i starijim (66 - 71 godina) sudionicima prezentirali isječke u trajanju od 20 sekundi 60 pjesama s top-ljestvica od 1935. do 1994. godine. Nakon slušanja svakog isječka sudionicima je prezentiran stih pjesme (koji nije bio u odslušanom isječku), a njihov je zadatak bio nastaviti tekst pjesme. Utvrđeno je kako se mlađi sudionici bolje sjećaju novijih pjesama, a stariji starijih pjesama. S obzirom na njihovu različitu dob sudionici su tijekom života bili različito izloženi prezentiranim pjesmama, pa je ovaj nalaz očekivan. No, rezultati su pokazali i da se mlađi sudionici bolje prisjećaju novijih pjesama nego što se stariji sudionici prisjećaju starijih pjesama. Točnost odgovora mlađih sudionika dosezala je otprilike $50 \%$, dok je točnost odgovora starijih sudionika dosezala oko 20\%. Drugim riječima, čini se kako pamćenje uglazbljenog materijala kroz duži vremenski period ipak slabi.

Schulkind i sur. (1999; Schulkind, 2009) navode kako je točnost dosjećanja informacija vezanih uz skladbe slična dosjećanju imena i lica školskih kolega. Time sugeriraju sličnost u upamćivanju "glazbenih" i informacija drugih vrsta. Ovo je shvaćanje također u suprotnosti s uvriježenim mišljenjem da glazba može spriječiti zaboravljanje informacija u poznoj dobi jer su imena i lica školskih kolega sadržaji koji pokazuju znatno zaboravljanje (Schulkind, 2009). Općenito, čini se kako se pozitivan utjecaj glazbe na pamćenje materijala ne iskazuje ispitivanjem neposredno nakon slušanja skladbe, već se pojavljuje tek nakon nekog vremena (npr. nekoliko tjedana), nakon čega opet nestaje. Schulkind (2009) zaključuje kako se na temelju 
sadašnjih podataka ne može zaključiti da postoje uvjerljivi dokazi o pozitivnom utjecaju glazbe na pamćenje.

\section{Glazba kao mogući mnemonik}

U dosadašnjim je istraživanjima utjecaja uglazbljenosti na dosjećanje korišteni materijal često bio isključivo vokalne prirode (Kilgour i sur., 2000; Rainey i Larsen, 2002; Wallace, 1994), a eksperimentalno je manipulirano je li tekst pjevan ili govoren. Osim toga, istraživano je pamćenje teksta prezentiranog uz pratnju metronoma (Wallace, 1994), bubnjeva (Purnell-Webb i Speelman, 2008) te složenu glazbenu pratnju većeg broja instrumenata (Calvert i Tart, 1993; Gingold i Abravanel, 1987; McElhinney i Annett, 1996). Navedena istraživanja upućuju na nejednoznačne rezultate o utjecaju uglazbljenosti materijala na pamćenje. Također, nedostaju i istraživanja toga kako varijacije u stupnju uglazbljenosti teksta, nastale korištenjem većeg broja instrumenata $\mathrm{i} / \mathrm{ili}$ različitih melodija, utječu na pamćenje teksta skladbe.

Teoretski razlozi zbog kojih bi tekst višeg stupnja uglazbljenosti mogao biti bolje upamćen od teksta nižeg stupnja uglazbljenosti leže u dvostrukim znakovima za pronalaženje. Primjerice, Rubin i Wallaceova (1989) su sudionicima u zadatku pamćenja zadavali jednostruke ili dvostruke znakove za pronalaženje. Jednostruki su znakovi bili rima i značenje, a dvostruki je znak bio kombinacija jednostrukih znakova. Zadatak je sudionika bio na temelju jednostrukog ili dvostrukih znakova generirati ciljnu riječ. Primjerice, sudionicima je dana informacija da se riječ koju trebaju generirati rimuje s "ed" ili da se radi o riječi za boju (jednostruki znaci), ili su im dane obje navedene informacije (dvostruki znak). U ovom je slučaju ciljna riječ koju su trebali generirati "crveno" (engl. red). Autori zaključuju kako je vjerojatnost generiranja ciljne riječi, uz dvostruki znak za pronalaženje, veća od zbroja vjerojatnosti generiranja ciljne riječi na temelju jednostrukih znakova koji zajedno tvore dvostruki znak. Wallaceova (1994) navodi kako glazba osigurava dvostruki znak za pronalaženje temeljem jednostrukih znakova kao što su notna sekvenca, ritam ili broj slogova. Glazba se, dakle, može shvatiti kao dvostruki znak sastavljen od melodije i značenja teksta, koji zasebno predstavljaju jednostruke znakove te je očekivano da će upamćivanje biti bolje ako je skladba vokalno-instrumentalna, nego samo vokalna ili samo instrumentalna.

Sukladno tome, ako je neka skladba snimljena korištenjem dva glazbena instrumenta, za pretpostaviti je da se svaki od ta dva instrumenta može shvatiti kao jednostruki znak za pronalaženje koji zajedno tvore dvostruki znak. Iz rezultata prethodno opisanog istraživanja Rubina i Wallaceove (1989) slijedi zaključak kako će dosjećanje teksta praćenog sviranjem dva glazbena instrumenta biti bolje od dosjećanja teksta praćenog sviranjem samo jednog od instrumenata. Taj bi efekt trebao biti toliko izražen da bi zbroj mjera dosjećanja teksta praćenog prvim instrumentom i praćenog drugim instrumentom trebao biti manji od mjere dosjećanja 
teksta praćenog $\mathrm{s}$ oba instrumenta. Pritom daljnju prednost upamćivanju uglazbljenog materijala daju i nalazi o tome da se tekst i melodija skladbe ne pamte odvojeno. Serafine i suradnici (Serafine, Crowder i Repp, 1984; Serafine, Davidson, Crowder i Repp, 1986) su sudionicima prezentirali isječke skladbi, nakon čega je uslijedila prezentacija isječaka u kojima je, u odnosu na prve isječke, izmijenjena melodija, tekst, nijedno ili oboje. Utvrđeno je kako se melodija bolje prepoznaje ako je tekst isti kao i u prvom slušanju te kako se bolje prepoznaje tekst ako je melodija ista kao i u prvom slušanju. Na temelju tih rezultata autori zaključuju kako se tekst i melodija u pamćenje pohranjuju integrirano, a ne odvojeno.

Čini se kako različit stupanj uglazbljenosti materijala osigurava prostor za upotrebu različitih strategija upamćivanja materijala. Naime, strategije upamćivanja teksta i melodija uglavnom se razlikuju. Pri upamćivanju se tekstualnog materijala koristi veći broj strategija nego pri upamćivanju melodija. Strategije koje se najčešće koriste pri upamćivanju tekstualnog materijala temelje se na korištenju prethodno pohranjenih informacija koje se na različite načine, ovisno o upotrijebljenoj strategiji, povezuju s informacijama koje se želi pohraniti. Tako se pri upamćivanju tekstualnog materijala najčešće rabe vizualizacije (Paivio, 1969), asocijacije (Bradshaw i Anderson, 1982) i orijentacija na značenje riječi (Elias i Perfetti, 1973). Uz to, već i subvokalno ponavljanje materijala (engl. rote rehearsal) dovodi do boljeg zadržavanja informacija u kratkoročnom pamćenju, čime se stvara bolja osnova za njihovo prenošenje u dugoročno pamćenje (Baddeley, 1968; Rundus, 1977). Strategije upamćivanja melodija temelje se na akustičnoj prirodi materijala, odnosno melodije, a u pamćenju se pohranjuju dvije komponente melodije: tonalitet i visine svih tonova koji čine melodiju (Dowling, 1978). Pokušaji verbalnog pamćenja melodije kojima se povezuje visina svakog tona s njegovim trajanjem te se potom pamti redoslijed tih nota pokazuju se vrlo neučinkovitima (Mikumo, 1992). Imajući $\mathrm{u}$ vidu da se istovremeno prezentiran tekst i melodija ne pamte odvojeno (Serafine i sur., 1984, 1986), valja očekivati je da će se pri pamćenju vokalno-instrumentalnog materijala (skladbi) ljudi koristiti strategijama za pamćenje tekstualnog materijala i strategijama pamćenja melodija. Sukladno tome, može se očekivati kako će s porastom stupnja uglazbljenosti skladbe rasti i upotreba strategija upamćivanja temeljenih na njenoj melodioznosti (tonalitet, visina tonova).

Na upamćivanje materijala ne utječu samo primjenjive strategije već i same karakteristike materijala koji treba upamtiti. Primjerice, rima (Bower i Bolton, 1969; Silverman, 2007) i ritam (Adams, 1915; Fallon, Groves i Tehan, 1999) mogu značajno osnažiti upamćivanje teksta. Nadalje, smislenost materijala daljnja je važna karakteristika koja pomaže upamćivanju. Besmislen se materijal, često korišten u eksperimentima, teže pamti od smislena (Davis, 1930; Epstein, Rock i Zuckerman, 1960). Karakteristike materijala olakšavaju ili otežavaju primjenu nekih strategija. Primjerice, rima zbog fonološke sličnosti između riječi olakšava akustičko kodiranje. Slično tome, i ritam olakšava akustičko kodiranje, dok apstraktnost materijala otežava stvaranje asocijacija. Očekivano je stoga da će se porastom stupnja 
uglazbljenosti materijala više koristiti karakteristike materijala koje olakšavaju upotrebu strategija pamćenja melodija.

Iako se čini kako istraživanja osiguravaju argumente zbog kojih se glazba može smatrati dobrim mnemonikom, treba imati na umu i kontraargumente. Naime, $u$ većini je suvremenih skladbi sadržan veći broj instrumenata. Primjerice, u pop- i rock-skladbama najčešće se koriste gitare (bas, akustična, električna) i ostali žičani instrumenti (violina, violončelo), bubnjevi i udaraljke, instrumenti s tipkama (klavir, sintesajzer) (Frith, Straw i Street, 2001). Moguće je da velik broj instrumenata stvara kontraefekt $u$ pokušajima upamćivanja, odnosno da zbog velikog broja instrumenata glazba postaje karakteristika koja odmaže, a ne pomaže pamćenju. Primjerice, Racette i Peretz (2007) ne pronalaze pozitivan utjecaj uglazbljenosti na pamćenje te čak utvrđuju negativan učinak ako je zadatak ispitanika pjevati (a ne pisati ili govoriti) stihove kojih se dosjete. Također, primjećuju kako "nije očito zašto bi glazba trebala facilitirati dosjećanje riječi budući da u pjesmi ima više za naučiti negoli u tekstu" (Racette i Peretz, 2007, str. 242). Moguće je da povećanje broja instrumenata otežava usmjeravanje pažnje na melodijsku liniju koja sadrži tekst. Međutim, s obzirom na široko rasprostranjeno uvjerenje da glazba potpomaže pamćenju moguće je da se pri upamćivanju svi instrumenti prisutni u skladbi kombiniraju stvarajući tako višestruke znakove za pronalaženje.

\section{Cilj istraživanja}

Cilj je ovog istraživanja bio ispitati utjecaj stupnja uglazbljenosti teksta na pamćenje tog teksta $\mathrm{i}$ istražiti strategije $\mathrm{u}$ podlozi razlika u upamćivanju teksta različitog stupnja uglazbljenosti, kao i karakteristike materijala koje mogu pri tome pomoći. Konkretno, ispitivali smo hoće li se razlikovati količina upamćenog materijala s obzirom na to je li on zadan samo vokalno, uz bubnjeve ili uz potpunu instrumentalnu pratnju. Nadalje, ispitivalo se i što može pomagati upamćivanju materijala, odnosno koriste li sudionici pri pamćenju materijala različitog stupnja uglazbljenosti različite strategije te pomažu li im u upamćivanju različite karakteristike materijala. U skladu s literaturom, očekivali smo da će s porastom stupnja uglazbljenosti rasti i količina upamćenog materijala, upotreba strategija pamćenja orijentiranih na glazbu te korištenje karakteristika materijala koje pomažu upamćivanju, a temeljene su na glazbi.

\section{Metoda}

\section{Sudionici}

U istraživanju je sudjelovao 91 student Sveučilišta u Zagrebu ( $87 \%$ žene). Raspon je dobi sudionika bio $18-25$ godina $(M=19.6, S D=1.51)$. Osobe koje su pohađale glazbenu školu, trenutno sviraju glazbeni instrument ili su ga prestale 
svirati prije manje od 5 godina nisu sudjelovale $u$ istraživanju jer rezultati pojedinih istraživanja pokazuju da osobe s glazbenim iskustvom bolje pamte glazbeni materijal (Kilgour i sur., 2000) i na drugačiji način (Mikumo, 1992) od osoba bez glazbenog iskustva.

\section{Nacrt}

$U$ istraživanju je korišten mješovit eksperimentalni nacrt $s$ dvije nezavisne varijable: stupanj uglazbljenosti teksta (nezavisni dio) i redni broj ponavljanja (zavisni dio). Stupanj je uglazbljenosti teksta imao tri razine, odnosno korištene su tri prilagođene verzije iste skladbe: a capella izvedba (verzija 1), vokalna izvedba praćena bubnjevima (verzija 2) i potpuno uglazbljena vokalna izvedba (verzija 3). Sudionici su po slučaju raspoređeni u jedan od ovih uvjeta. Varijabla redni broj ponavljanja imala je šest razina: sudionici su skladbu slušali šest puta.

Prije slušanja skladbe sudionici su slušali snimku recitacije teksta skladbe kako bi se: a) osiguralo da su svi jednako upoznati s tekstom prije slušanja skladbe, b) smanjila vjerojatnost pogrešnog razumijevanja pojedinih riječi u tekstu, i c) osigurali uvjeti za provjeru jednakosti generalne sposobnosti pamćenja triju skupina sudionika. Snimka recitacije teksta skladbe nije korištena kao zasebna razina nezavisne varijable (kontrolna situacija) jer nalazi ranijih istraživanja pokazuju da je brzina prezentiranja riječi jedan od faktora koji su odgovorni za razlike u upamćivanju glazbenog i neglazbenog materijala (Kilgour i sur., 2000). Govor u kojem bi brzina prezentiranja riječi bila ista kao u skladbi, gdje je tekst pjevan, u ovom bi slučaju zvučao neprirodno sporo što bi moglo imati utjecaj na rezultate. Osim toga, nije bilo moguće pronaći istog vokalistu, pa bi se time u istraživanje uvela dodatna varijabla koju nije moguće kontrolirati.

Zavisna varijabla bila je broj upamćenih stihova skladbe. Detaljan opis bodovanja uratka sudionika nalazi se u Prilogu A. Raspon bodova kretao se od 0 do 16.5. Rezultate su svih sudionika bodovali prvi autor i troje dodatnih ispravljača. Svi su ispravljači upoznati sa sve tri verzije skladbe i snimkom recitacije teksta skladbe. Svi su ispravljači bodovali rezultate svih sudionika. Svaki je ispravljač zasebno donosio odluku o tome koliko će bodova za svaki napisan stih dodijeliti, uzimajući u obzir spomenute faktore. Aritmetička sredina bodova koje je sudionicima dodijelilo četvero ispravljača uzeta je kao mjera zavisne varijable. Stupanj slaganja procjena ispravljača (Krippendorffova alfa) iznosio je 0.93 .

Osim ove zavisne varijable, još su dvije zavisne varijable korištene $u$ istraživanju: čestina korištenih strategija upamćivanja i čestina korištenja karakteristika materijala kao pomoći pri upamćivanju. Mjera je svake od ovih zavisnih varijabli broj sudionika koji su naveli da su se koristili nekom strategijom upamćivanja, odnosno da im je pri upamćivanju pomogla ili odmogla neka karakteristika materijala. 


\section{Podražajni materijal}

Skladba. Skladba "Ako već brineš" ${ }^{1}$ rock-žanra u trajanju od 2 minute i 33 sekunde.

Ova skladba uključuje korištenje instrumenata karakterističnih za rock-žanr (električna gitara, bubnjevi, saksofon, akustični klavir) te sadrži jak i agresivan vokalni dio koji se razlikuje od vokala korištenih u klasičnom pjevanju čime, prema karakteristikama koje navode Shepherd, Horn, Laing, Oliver i Wicke (2003), predstavlja tipičnu rock-skladbu. Također, i njezina struktura odgovara strukturi skladbi tipičnih za rock-žanr: strofa, prijelaz, predrefren, refren, postrefren (Everett, 2008). Prikaz tijeka skladbe korištene u ovom istraživanju nalazi se na Slici 1. Tekst skladbe pisan je hrvatskim jezikom, apstraktan je i nema jasnu fabulu (Prilog B). Tekst je podijeljen na tri strofe i sastoji se od 88 riječi. Niti jedan se stih ne ponavlja. Vokalist je mlađa muška osoba. Vokalna i instrumentalna komponenta skladbe i različiti glazbeni instrumenti ne prate istu melodiju.

Za potrebe je istraživanja skladba modificirana te su stvorene tri verzije: 1) $a$ capella izvedba, 2) vokalna izvedba praćena bubnjevima u kojoj su uklonjeni svi instrumenti osim akustičnih i električnih bubnjeva, 3) potpuno uglazbljena vokalna izvedba u kojoj su prisutni svi instrumenti (električne gitare, bubnjevi, klavir, orgulje, saksofon). Osim u a capella izvedbi (verzija 1), ne postoje dijelovi skladbe u kojima nije prisutna instrumentalna komponenta skladbe. U vokalnoj izvedbi praćenoj bubnjevima (verzija 2) i u potpuno uglazbljenoj vokalnoj izvedbi (verzija 3) akustični i električni bubnjevi identični su i prisutni tijekom cijele skladbe. Vokalna je komponenta identična u sve tri verzije.

Slika 1. Prikaz tijeka skladbe korištene u istraživanju

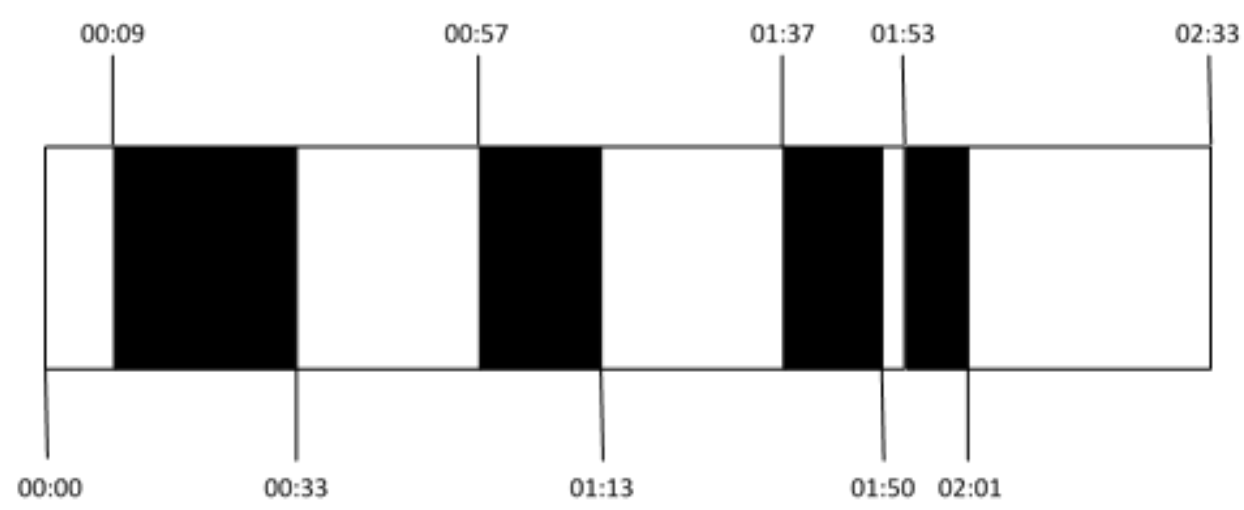

Napomena. Crna polja predstavljaju dijelove s vokalnom komponentom, a bijela dijelove bez vokalne komponente

\footnotetext{
${ }^{1}$ Uz dozvolu Marka Debogovića, nositelja autorskih prava.
} 
Snimka teksta. Kao 0. pokušaj (engl. baseline) sudionicima je prezentirana snimka recitacije teksta skladbe u trajanju od 45 sekundi. U snimci je korišten glas mlađe muške osobe. Tekst je recitiran razgovijetno.

\section{Pribor}

Prikupljeni su demografski podaci i podaci o glazbenoj naobrazbi sudionika (moguće pohađanje glazbene škole i sviranje instrumenta).

U Upitniku o strategijama sudionici su zamoljeni da: 1) ukratko opišu kako su pamtili tekst pjesme, 2) što im je pomoglo u upamćivanju i 3) što ih je ometalo pri upamćivanju. Također, u ovaj je upitnik uvršteno pitanje kojim se provjeravalo je li skladba sudionicima od ranije poznata.

Podražajni materijal prezentiran je pomoću računala sa zvučnicima. Sudionici su nakon slušanja materijala u protokole upisivali stihove koje su zapamtili.

\section{Postupak}

\section{Predistraživanje}

Prije glavnog istraživanja provedeno je predistraživanje u kojemu je sudjelovalo 18 sudionika (66\% žena). Nijedan sudionik predistraživanja nije pohađao glazbenu školu, a svi koji su u prošlosti svirali glazbeni instrument prestali su ga svirati prije više od 5 godina. Niti jedan od ovih sudionika nije sudjelovao u glavnom istraživanju. Postupak predistraživanja oponašao je postupak glavnog istraživanja. Sudionici su raspoređeni u tri eksperimentalne skupine te su slušali skladbu šest puta. Nakon svakog slušanja ispisivali su na protokole sav tekst koji su se mogli sjetiti. Nakon šestog ponavljanja ispunili su Upitnik o strategijama. Rezultate predistraživanja bodovali su eksperimentator i jedan dodatni ispravljač. Na temelju tih rezultata utvrđeno je da krivulja učenja teksta skladbe ne dostiže plato do šestog ponavljanja, stoga je odlučeno da u glavnom istraživanju broj slušanja skladbe ne bude manji od šest kako bi granica mjerenja bila što bliže početku stagnacije krivulje koji označava maksimalan rezultat kojeg sudionici mogu postići (Barlow, 1928). Također, utvrđeno je da je u glavnom istraživanju potrebno postaviti vremensko ograničenje od pet minuta za svako ponavljanje, a nisu pronađene značajne povezanosti između broja bodova i vremena potrebnog za svako ponavljanje. Analizom odgovora u Upitniku o strategijama definirano je pet strategija upamćivanja (spontano pamćenje, fokusiranje na određeni dio teksta, ponavljanje određenog dijela teksta, fokusiranje na semantičke elemente i vizualizacija), četiri karakteristike materijala koje pomažu (glazba, rima, priroda vokala i pauze u skladbi) i pet distraktivnih karakteristika materijala (pauze u skladbi, apstraktnost teksta, priroda vokala, nedostatak glazbe, neuobičajenost riječi korištenih u tekstu). 
Naposljetku, na temelju je primjedaba sudionika trajanje završnog dijela skladbe bez vokalne komponente skraćeno za 40 sekundi, čime je trajanje skladbe skraćeno s 3 minute i 13 sekundi na 2 minute i 33 sekunde.

\section{Glavno istraživanje}

Mjerenje je provedeno individualno, u laboratorijskim uvjetima. Uvjeti rasvjete i glasnoće zvuka držani su konstantnima. Sudionicima je pročitana uputa kojom su zamoljeni da nikome ne odaju tekst skladbe. Nakon davanja demografskih podataka sudionici su jednom poslušali snimku recitacije teksta skladbe. Tijekom ove snimke na uvid im je dan ispisan tekst skladbe (0. pokušaj). Čitanjem i istovremenim slušanjem teksta nastojalo se izbjeći oslabljeno pamćenje teksta zbog njegove eventualne nerazgovijetnosti ili nerazumijevanja snimke. Snimka recitacije bila je ista u sve tri eksperimentalne skupine. Nakon toga je sudionik slušao skladbu šest puta, pri čemu nije imao pristup tekstu skladbe. Nakon slušanja recitacije teksta i nakon svakog slušanja skladbe sudionik je zapisivao sav tekst skladbe koji se mogao sjetiti uz vremensko ograničenje od pet minuta po ponavljanju, pri čemu nije imao pristup tekstu skladbe ni stihovima koje je ispisao u svojim prethodnim ponavljanjima. Na kraju je svaki sudionik ispunio Upitnik o strategijama. Nijedan sudionik nije izjavio da mu je skladba od ranije poznata. Eksperiment je trajao oko sat vremena po sudioniku.

Protokole za dosjećanje teksta skladbe anonimno su bodovala četiri ispravljača nakon što su svi sudionici ispitani. Ispravljači su dobili detaljne pismene upute o načinu bodovanja. Ispravljač nije imao uvid u bodove drugih ispravljača. Redoslijed bodovanja protokola za svakog ispravljača određen je slučajnim rasporedom. Kako bi se spriječila mogućnost pogrešnog rasporeda protokola, na poleđinu svih protokola zalijepljene su naljepnice s QR-kodovima koji su sadržavali brojčane oznake sudionika. Prilikom rotacije protokola ispravnost je poretka potvrđena skeniranjem QR-kodova.

\section{Rezultati}

Jednosmjernom je analizom varijance za nezavisne uzorke utvrđeno da se tri eksperimentalne skupine ne razlikuju po broju bodova u 0 . pokušaju, $F(2,88)=0.745$, $p=.478, \eta^{2}=0.017$. Drugim riječima, sudionici se triju eksperimentalnih skupina nisu razlikovali u općoj sposobnosti pamćenja.

Analizom je varijance za mješovite uzorke $(6 \times 3)$ utvrđeno da je glavni efekt rednog broja ponavljanja statistički značajan uz visoku veličinu učinka, $F(5,440)=1011.273, p<.01, \eta^{2=} 0.92$. Bonferronijevim je post hoc-testom utvrđeno da je broj bodova u svakom ponavljanju statistički značajno veći u odnosu na prethodno. Nije utvrđen značajan glavni efekt stupnja uglazbljenosti, $F(2,88)=0.171$, 
$p=.843, \eta^{2}=0.004$, kao ni značajna interakcija, $F(10,440)=0.681, p=.742, \eta^{2}=0.015$ (Slika 2.).

\section{Slika 2. Broj bodova ovisno o rednom broju ponavljanja $i$} stupnju uglazbljenosti teksta $(N=91)$

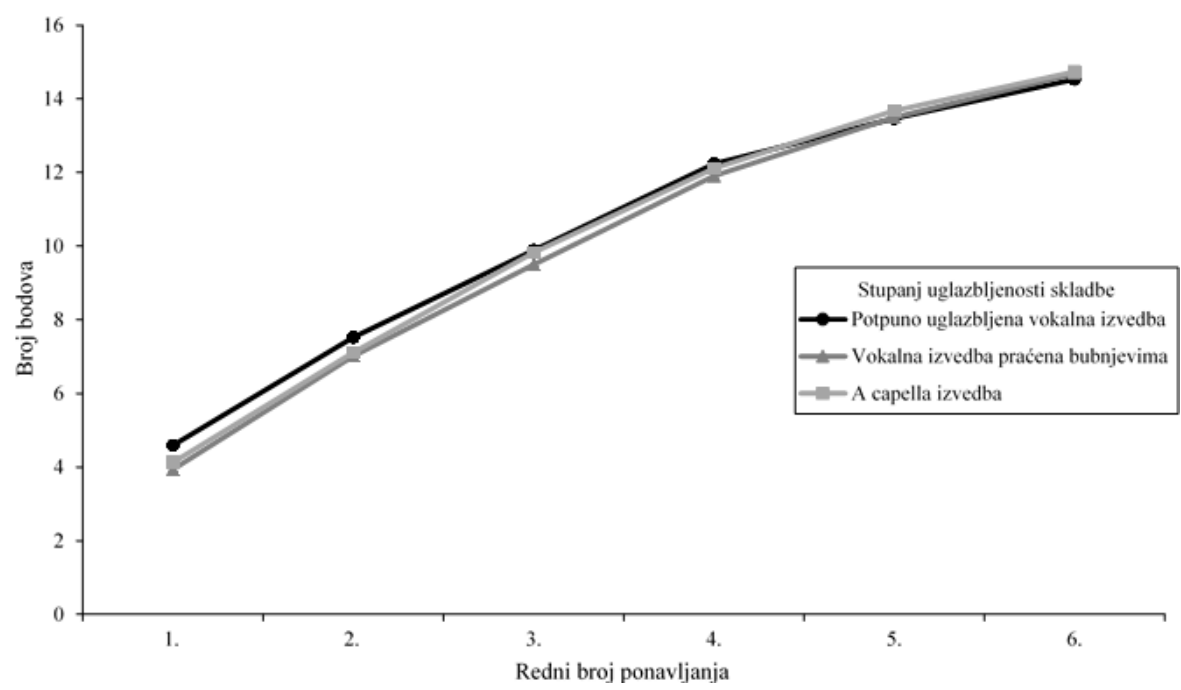

U Upitniku o strategijama sudionici su pitani o strategijama i karakteristikama materijala koji eventualno pomažu ili odmažu pri upamćivanju. Analizom je odgovora sudionika glavnog istraživanja strategijama koje su utvrđene predistraživanjem pridodana i strategija asociranja. Time je ukupno analizirano šest mogućih strategija prilikom upamćivanja teksta.

Hi-kvadrat testom nije utvrđena statistički značajna razlika između grupa $\mathrm{u}$ čestini korištenja spontanog pamćenja, $\chi^{2}(2)=2.914, p=.233$, ponavljanja određenog dijela teksta, $\chi^{2}(2)=1.46, p=.482$, asociranja, $\chi^{2}(2)=3.135, p=.209$, vizualizacije, $\chi^{2}(2)=0.784, p=.676$, fokusiranja na određeni dio teksta, $\chi^{2}(2)=1.127, p=.569 \mathrm{i}$ fokusiranja na semantičke elemente, $\chi^{2}(2)=0.267, p=.875$, odnosno niti jedne strategije pamćenja.

Uz četiri karakteristike materijala koje pomažu pri upamćivanju definirane predistraživanjem (glazba, rima, priroda vokala i pauze u skladbi) definirane su dodatne tri: ritam, priroda riječi i poznavanje broja slogova u stihovima. Budući da su čestine pojave nekih karakteristika u pojedinim skupinama manje od pet, korišten je Fisherov egzaktni test, kojim su utvrđene dvije statistički značajne razlike u čestini navođenja pojedinih karakteristika koje pomažu pri pamćenju teksta ovisno o stupnju uglazbljenosti - glazba $(p=.003)$ i priroda vokala $(p=.031)$.

Kako je riječ o omnibus-testu, ne može se sa sigurnošću utvrditi između kojih se grupa sudionika pojavljuje značajna razlika u čestini korištenja glazbe kao pomoći 
pri upamćivanju, no na osnovi bruto rezultata čini se kako postoji trend da porastom uglazbljenosti teksta raste i broj sudionika koji glazbu koriste kao pomoć pri upamćivanju (Slika 3.). Broj sudionika koji su izjavili da im je u pamćenju pomogla priroda vokala veći je u skupini koja je slušala a capella izvedbu nego u druge dvije skupine, u kojima je izjednačen broj sudionika kojima priroda vokala pomaže pri upamćivanju. Point-biserijalni koeficijenti korelacije između čestine pojave svake od ovih dviju kategorija i broja bodova nisu statistički značajni. Fisherovim egzaktnim testom nisu pronađene statistički značajne razlike između grupa za karakteristike rime ( $p=.446)$, pauza u skladbi $(p=.739)$, ritma $(p=.427)$, prirode riječi $(p=.619)$ te poznavanja broja slogova u stihovima $(p=.543)$.

\section{Slika 3. Čestine pojave karakteristika materijala koje pomažu pri pamćenju ovisno o stupnju uglazbljenosti teksta}

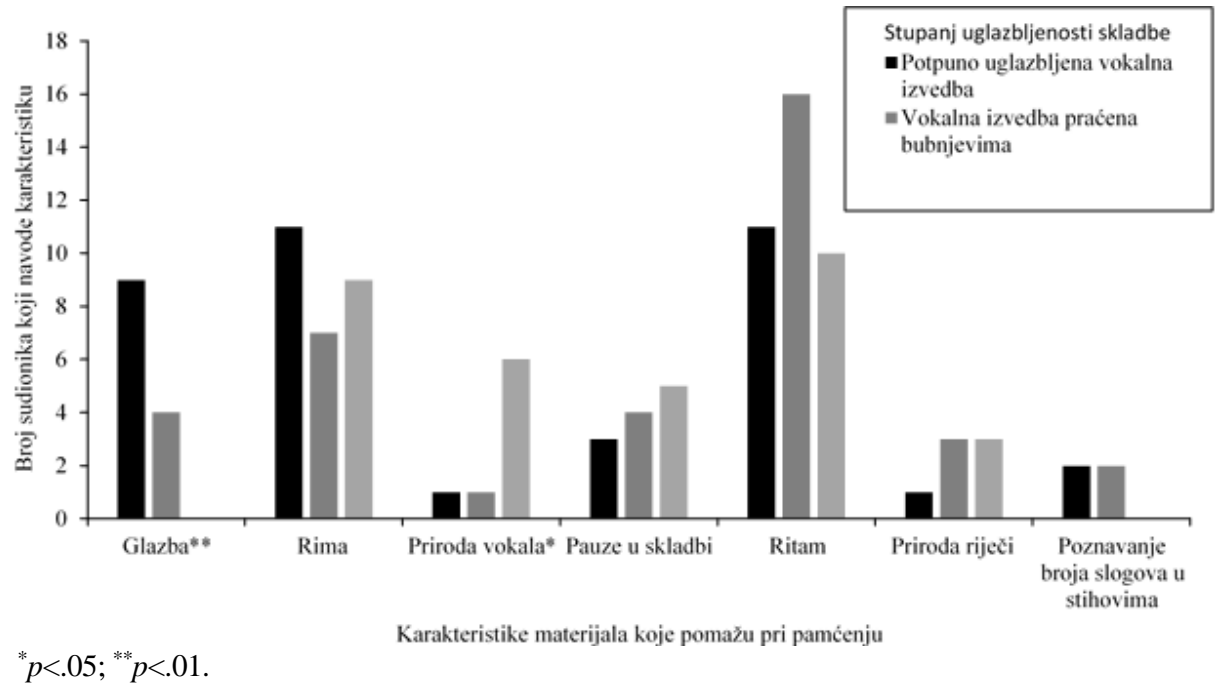

Uz pet distraktivnih karakteristika materijala definiranih predistraživanjem (pauze u skladbi, apstraktnost teksta, priroda vokala, nedostatak glazbe, neuobičajenost riječi korištenih u tekstu) definirane su još tri: količina teksta, nejednaka duljina stihova i nedostatak rime. Fisherovim egzaktnim testom nije utvrđena statistički značajna razlika između grupa za karakteristike pauza u skladbi $(p=1)$, apstraktnosti teksta $(p=.541)$, prirode vokala $(p=.741)$, nedostatka glazbe $(p=.415)$, neuobičajenosti riječi korištenih u tekstu $(p=.195)$, količine teksta ( $p=.436)$, nejednake duljine stihova $(p=1)$ i nedostatka rime ( $p=.436)$, odnosno ni za jednu distraktivnu karakteristiku.

Nijedan point-biserijalni koeficijent korelacije između broja postignutih bodova u posljednjem pokušaju i korištenih strategija pamćenja nije bio statistički značajan. Također, point-biserijalni koeficijenti korelacije između broja bodova u posljednjem 
pokušaju i korištenja karakteristika materijala kao pomoći pri upamćivanju, kao ni između broja bodova u posljednjem pokušaju i ometenosti distraktivnim karakteristikama materijala, nisu bili statistički značajni.

\section{Rasprava}

Suprotno očekivanjima, sudionici koji su slušali skladbu višeg stupnja uglazbljenosti nisu zapamtili više stihova od sudionika koji su slušali skladbu nižeg stupnja uglazbljenosti. Sve su tri skupine zapamtile podjednak broj stihova skladbe. Drugim riječima, stupanj uglazbljenosti teksta nije utjecao na broj zapamćenih stihova skladbe. Prethodna istraživanja sugeriraju da glazba nema pozitivan utjecaj na pamćenje (Schulkind, 2009), a rezultati ovog istraživanja pokazuju da stupanj uglazbljenosti ne utječe na pamćenje. No, u suprotnosti s očekivanjima je nalaz da stupanj uglazbljenosti nije utjecao na čestinu korištenja određenih strategija upamćivanja. Od karakteristika materijala koje pomažu pri upamćivanju, utvrđene su dvije koje variraju ovisno o stupnju uglazbljenosti teksta - glazba i priroda vokala. O glazbi kao pomoći pri upamćivanju izvještavaju sudionici koji su slušali vokalnu izvedbu praćenu bubnjevima i oni koji su slušali potpuno uglazbljenu vokalnu izvedbu te se čini kako je među potonjima bilo više onih koji navode da im je glazba olakšavala upamćivanje. Broj sudionika koji su izjavili da im je u pamćenju teksta pomogla priroda vokala bio je veći u skupini koja je slušala a capella izvedbu u usporedbi s preostale dvije skupine među kojima nije bilo razlike. Karakteristika Priroda vokala u skupini koja je slušala a capella verziju skladbe analogan je karakteristici Glazba u ostale dvije skupine: u a capella verziji skladbe nema instrumentalne komponente skladbe, što vokal čini jedinim preostalim elementom skladbe koji ima melodiju. Sudionici koji su slušali a capella verziju skladbe vjerojatno smatraju da im je pri pamćenju teksta skladbe pomogla priroda vokala na isti način na koji sudionici koji su slušali ostale dvije verzije skladbe smatraju da im je pri pamćenju teksta skladbe pomogla glazba.

Prikupljene izjave sudionika pokazuju kako sudionici imaju dojam da im uglazbljenost olakšava upamćivanje. Naime, iako ispitanici izjavljuju da im glazba pomaže, rezultati istraživanja to ne potvrđuju. U sve tri skupine sudionici izjavljuju kako su im pri upamćivanju teksta pomogle one karakteristike materijala koje imaju melodiju. U prisutnosti instrumentalne melodije (verzije 2 i 3 ) sudionici se manje orijentiraju na vokalnu melodiju zbog čega skupine koje su slušale verzije 2 i 3 rjeđe navode da im je pomogla priroda vokala od skupine koja je slušala verziju 1. Moguće je da glazba na pamćenje djeluje tako da smanjuje trud koji je potrebno uložiti u pamćenje zato što djeluje kao dvostruki znak za pronalaženje (Rubin i Wallace, 1989). Međutim, postoji nekoliko činjenica koje nisu u skladu s takvim zaključkom. Tri se skupine ne razlikuju u količini teksta kojeg su se dosjetili, tj. u broju ostvarenih bodova. Kada bi uglazbljenost pomagala pamćenju putem dvostrukih ili višestrukih znakova za pronalaženje, očekivala bi se razlika u pamćenju ovisno o broju 
dostupnih znakova za pronalaženje, koji se povećava povećanjem stupnja uglazbljenosti. No, kako nije utvrđeno da broj bodova ovisi o stupnju uglazbljenosti, ne može se govoriti o glazbi kao distraktoru.

Također, s obzirom na različitost materijala, između skupina bi se očekivala razlika u korištenju strategija upamćivanja i karakteristikama tog materijala koje utječu na pamćenje. Takve razlike u ovom istraživanju nisu utvrđene: sudionici se razlikuju jedino po karakteristikama Glazba i Priroda vokala, no njih možemo smatrati analognima jer se odnose na one elemente materijala koji imaju melodiju. Čestina uporabe ponavljanja, jedine strategije koju se može smatrati strategijom upamćivanja melodije (jer sudionici mogu subvokalno tekst pjevati po melodiji), prema rezultatima ovog istraživanja ne razlikuje se među skupinama koje su slušale skladbu različitog stupnja uglazbljenosti. Naravno, sudionici nisu bili upućeni pamtiti melodiju, već tekst, no dosadašnja istraživanja pokazuju da se melodija i tekst u pamćenje pohranjuju integrirano (Serafine i sur., 1984, 1986). Uz pretpostavku kako se integrirano ne pohranjuju samo tekst skladbe i glavna melodija koja prati taj tekst, već i melodije ostalih instrumenata, može se očekivati da se sudionici u nekoj mjeri koriste strategijama za upamćivanje melodije unatoč tome što melodiju ne moraju pamtiti. Sukladno ovoj pretpostavci, s porastom stupnja uglazbljenosti moglo bi doći do porasta u korištenju takvih strategija, no ovu bi pretpostavku trebalo podrobnije ispitati budućim istraživanjima.

Ovi rezultati sugeriraju kako ljudi zapravo samo imaju dojam da im uglazbljenost pomaže u pamćenju, što podupire i dio nalaza. Sudionici koji su izjavili da im je pri pamćenju teksta pomogla glazba nisu zapamtili više stihova od onih koji to nisu izjavili (nema povezanosti čestine upotrebe Glazbe kao karakteristike koja pomaže upamćivanju i broja bodova). Sukladno tome, sudionici koji su izjavili da im je pri upamćivanju pomogla Priroda vokala nisu zapamtili više stihova od onih koji to ne izjavljuju (nema povezanosti čestine upotrebe Prirode vokala i broja bodova). Pritom se sudionici, neovisno o prezentiranom materijalu, ne razlikuju u tome da navode neke druge karakteristike materijala koje su im mogle pomoći u upamćivanju. Također, sudionici se nisu razlikovali ni u korištenju drugačijih strategija za upamćivanje, neovisno o stupnju uglazbljenosti materijala koji su trebali upamtiti. Spomenutu hipotezu na neki način podupire i činjenica da ne postoji statistički značajna razlika u čestini pojave karakteristike Nedostatak glazbe (kao distraktivne karakteristike materijala) između eksperimentalnih skupina (kod sve tri skupine čestina pojave te karakteristike je neznatna: iznosi nula ili blizu nule). Drugim riječima, kao što, čini se, uglazbljenost ne pomaže pamćenju, tako ni nedostatak glazbe ne odmaže pamćenju. No, sudionici imaju dojam da im uglazbljenost materijala pomaže, a skupine koje su slušale verzije 2 i 3 to i izjavljuju. Sudionici koji su slušali a capella verziju skladbe također vjeruju da uglazbljenost pomaže pamćenju, a pronalaze ju u prirodi vokala jer je vokal jedini element $a$ capella skladbe koji ima melodiju. Ipak, iako su sve skupine morale obratiti pozornost na vokal zbog zadatka upamćivanja teksta, skupine koje su slušale verzije 
2 i 3 ne pripisuju svoje pamćenje prirodi vokala premda im je jednako dostupan kao i skupini koja je slušala verziju 1 jer su svoje pamćenje već, u skladu sa svojim vjerovanjima, pripisali glazbi.

Priroda vjerovanja o uglazbljenosti kao karakteristici materijala koji pomaže pri upamćivanju rijetko su istraživana, posebice eksperimentalno. Međutim, moguće ih je teoretski objasniti kovarijacijskim modelom atribucije (Kelley, 1973). Prema ovom modelu, ljudi pripisuju neku posljedicu onom uzroku s kojim posljedica tijekom vremena kovarira. Pritom se koriste informacijama o konsenzusu, konzistentnosti i distinktivnosti uzroka i posljedica. Konsenzus se odnosi na kovariranje ponašanja između različitih osoba, konzistentnost na kovariranje ponašanja tijekom vremena, a distinktivnost na kovariranje ponašanja između različitih situacija. Tako, pripisuju li ljudi poboljšano pamćenje materijala glazbi dakle, podražaju - prema kovarijacijskom modelu atribucije konsenzus, konzistentnost i distinktivnost tog podražaja su visoki (Hewstone i Jaspars, 1987). Drugim riječima, ljudi percipiraju kako uglazbljenost poboljšava pamćenje materijala kod svih osoba (visok konsezus), stabilno kroz vrijeme (visoka konzistentnost) te kako se poboljšano pamćenje nekog materijala javlja samo u onim situacijama kad je taj materijal praćen glazbom (visoka distinktivnost). U objašnjenje se nalaza ovog istraživanja mogu predložiti dvije hipoteze u okviru kovarijacijskog modela atribucije - pogrešno percipirana visoka distinktivnost pamćenja glazbenog materijala i pogrešno percipirana visoka konzistentnost pamćenja glazbenog materijala.

Naime, za razliku od laičkih uvjerenja da uglazbljenost olakšava upamćivanje rezultati većeg broja istraživanja sugeriraju kako ona nema utjecaja na dosjećanje (Kilgour i sur., 2000; Racette i Peretz, 2007; Rainey i Larsen, 2002; Schulkind, 2009). Prema predloženoj hipotezi o pogrešno percipiranoj visokoj distinktivnosti pamćenja glazbenog materijala laička vjerovanja i znanstveni podaci o utjecaju uglazbljenosti na upamćivanje razlikuju se u dimenziji distinktivnosti. Laici vjerojatno smatraju kako je distinktivnost glazbe i svakodnevnog materijala visoka - drugim riječima, poboljšano se pamćenje javlja samo ako je tekst praćen glazbom. Suprotno tome, znanstveni podaci pokazuju da je distinktivnost niska, odnosno tekst se pamti jednako neovisno o tome je li uglazbljen ili ne. Moguć je razlog različitog poimanja distinktivnosti upamćivanja uglazbljenog materijala često uspoređivanje pamćenja stihova skladbi i pamćenja školskog gradiva na osnovi njihova verbalnog karaktera. Naime, tekstovi skladbi i školsko gradivo su materijali s kojima se, posebice mlađe osobe kakve su sudjelovale u ovom istraživanju, relativno često svakodnevno susreću. Ujedno, ti materijali sadrže velike količine teksta, pa ih je intuitivnije međusobno uspoređivati, nego, primjerice, uspoređivati pamćenje teksta skladbe i pamćenje lica. Međutim, ono što se pri ovoj usporedbi možda ne uzima u obzir je značajno veća količina teksta i informacija sadržana u tipičnom školskom gradivu, kao i brojni drugi faktori potrebni za upamćivanje velike količine školskog sadržaja (npr. motivacija, prethodno znanje). Atribucijski je zaključak koji se iz 
ovoga dade izvesti da je pamćenje uglazbljenog materijala bolje od pamćenja teže pamtljivog školskog gradiva.

Prema predloženoj hipotezi o pogrešno percipiranoj visokoj konzistentnosti pamćenja glazbenog materijala laičko poimanje i znanstveni podaci također se razlikuju. Prema laičkom poimanju glazba poboljšava pamćenje u vremenskim intervalima svih duljina (visoka konzistentnost) dok znanstveni podaci sugeriraju da glazba poboljšava pamćenje samo u umjereno dugim vremenskim intervalima (niska konzistentnost). Primjerice, Rainey i Larsen (2002) navode kako su sudionici koji su slušali pjevan tekst bolje pamtili od onih koji su slušali govoren tekst. Ova je razlika utvrđena tjedan dana nakon slušanja, dok pri neposrednom ispitivanju pamćenja teksta nije bilo razlika među grupama. Dakle, pozitivan bi utjecaj glazbe na pamćenje mogao biti zamjetan jedino pri odgođenom ispitivanju (Schulkind, 2009). U tom slučaju, laičko shvaćanje da uglazbljenost potpomaže pamćenju nije u potpunosti netočno jer se čini da pomaže dužoj retenciji sadržaja. No, ova hipoteza ostaje za daljnju provjeru.

Moguć razlog pogrešnog pripisivanja pozitivnog utjecaja uglazbljenosti teksta na njegovo upamćivanje jest taj što nakon kratkih intervala rijetko dolazi do preispitivanja vlastitog pamćenja teksta skladbi. Ako se to pak dogodi, pamćenje se pripisuje nedavnom slušanju skladbe. Također, rjeđe dolazi i do preispitivanja nakon izrazito dugih vremenskih intervala. Dakle, vremenska točka u kojoj dolazi do preispitivanja jest po prolasku umjereno velike količine vremena od slušanja skladbe, upravo kada postoji pozitivan utjecaj uglazbljenosti na retenciju teksta, odnosno kad je i distinktivnost visoka. Budući da je do prednosti uglazbljenog teksta nad ostalim vrstama materijala došlo u svim vremenskim točkama u kojima je došlo do preispitivanja, konzistentnost se percipira kao visoka.

Smatraju li ljudi da se uglazbljen tekst pamti bolje od neuglazbljenog, moguće je i da smatraju da se pozitivan efekt glazbe povećava sa stupnjem uglazbljenosti, no to je svakako potrebno provjeriti daljnjim istraživanjima. Pretpostavljeni bi se pozitivan utjecaj glazbe na retenciju teksta u umjereno dugim vremenskim intervalima mogao objasniti mogućnošću da ljudi češće razmišljaju o glazbi nego o drugim vrstama materijala, što poboljšava pamćenje vezano uz glazbu u odnosu na druge vrste materijala. Tako Calvert i Tart (1993) navode da su, za razliku od sudionika koji su slušali govoren tekst, sudionici koji su slušali uglazbljen tekst češće nenamjerno, odnosno spontano, ponavljali taj tekst subvokalno. Ovaj nalaz možda pojašnjava i to zašto glazba nema pozitivnog utjecaja na pamćenje vrši li se mjerenje neposredno nakon slušanja skladbe. Naime, čini se kako tada nije prošlo dovoljno vremena da bi se uglazbljen tekst subvokalno ponovio više puta od neuglazbljenog teksta. S druge strane, nakon vrlo dugih vremenskih intervala glazba nema pozitivnog utjecaja na pamćenje jer s vremenom interes za skladbu pada te se ona sve manje subvokalno ponavlja ili se čak prestaje ponavljati i osoba ne razmišlja više često o skladbi. Rjeđe razmišljanje o skladbi postupno dovodi do zaboravljanja 
njezina teksta i pamćenje uglazbljenog teksta s vremenom opada na razinu pamćenja neuglazbljenog teksta.

Zaključno, treba napomenuti kako hipoteza o pogrešno percipiranoj visokoj distinktivnosti pamćenja glazbenog materijala i hipoteza o pogrešno percipiranoj visokoj konzistentnosti pamćenja glazbenog materijala nisu međusobno isključive. Moguće je da su i distinktivnost i konzistentnost niske, a ljudi ih obje percipiraju visokima.

\section{Ograničenja}

Naposljetku, potrebno je osvrnuti se i na neka ograničenja ovog istraživanja. Ona se prvenstveno odnose na odabir materijala (skladbe) te ispitivani period retencije.

Vezano uz odabir materijala Gingold i Abravanel (1987) razlikuju "dobru" i "lošu" glazbu (engl. good and bad music) ovisno o tome jesu li u skladbi usklađene instrumentalna i vokalna melodija. "Dobra glazba", u kojoj postoji usklađenost instrumentalne i vokalne melodije, obično se pamti jednako dobro kao i govoren tekst. Skladba korištena u ovom istraživanju, s obzirom na nesuklađenost instrumentalne i vokalne komponente, predstavlja "lošu glazbu". Drugim riječima, postoji mogućnost da bi skupine koje su slušale verziju s bubnjevima i potpuno uglazbljenu verziju pokazale bolje rezultate od skupine koja je slušala a capella verziju skladbe da je u istraživanju korištena "dobra glazba". Međutim, u tom bi se slučaju očekivala i razlika u broju zapamćenih stihova između skupine koja je slušala potpuno uglazbljenu vokalnu izvedbu i one koja je slušala vokalnu izvedbu praćenu bubnjevima jer u potpuno uglazbljenoj vokalnoj izvedbi postoji više različitih melodija (potpuno uglazbljena vokalna izvedba je "lošija glazba" od vokalne izvedbe praćene bubnjevima). Skupina koja je slušala vokalnu izvedbu praćenu bubnjevima trebala bi, u ovom slučaju, zapamtiti više stihova od skupine koja je slušala potpuno uglazbljenu vokalnu izvedbu, što nije utvrđeno. Međutim, velik broj skladbi s kojima se ljudi susreću u svakodnevnom životu mogle bi se klasificirati kao "loša glazba" (a ljudi i u tim slučajevima smatraju da je lakše pamtiti uglazbljen tekst nego neuglazbljen), pa istraživanja koja upotrebljavaju "lošu glazbu" daju bolju sliku stvarnog stanja od istraživanja koja upotrebljavaju "dobru glazbu".

Osim toga, dodatna slabost odabrane skladbe leži u tome što postoje dijelovi skladbe bez vokalne komponente, što dovodi u pitanje mogućnost usporedbe tri eksperimentalne skupine. Naime, budući da skupina koja sluša a capella verziju skladbe tijekom trajanja tih dijelova nije izložena zvučnim podražajima, a ostale dvije skupine jesu, moguće je da se strategije pamćenja između tih skupina razlikuju, što se može odraziti i na količinu upamćenog teksta. No, rezultati ovog istraživanja pokazuju da se količina upamćenog teksta ne razlikuje ovisno o stupnju uglazbljenosti. Također, strategije pamćenja ne razlikuju se ni između triju eksperimentalnih skupina. Na temelju ovih rezultata može se zaključiti da postojanje 
dijelova skladbe bez vokalne komponente nije utjecalo na unutarnju valjanost, a njihova prisutnost, kao što je ranije opisano, povećava vanjsku valjanost.

Nadalje, skladba koja je korištena kao podražajni materijal po svojoj prirodi predstavlja apstraktan tekst, koji nema izravno jasnu fabulu. U tom je smislu upamćivanje ovog materijala bilo otežano, odnosno očekivano je da je ono teže negoli su mnoge situacije svakodnevnog pamćenja, primjerice, čitanja vijesti ili uputa, koje zahtijevaju upamćivanje koherentnih cjelina. U ovom je istraživanju primijenjena skladba u manjoj mjeri omogućavala uobičajene strategije upamćivanja (npr. korištenje shema, povezivanje starog s novim). Predmet je ovog istraživanja bio stupanj uglazbljenosti materijala kao moguća pomoć upamćivanju te smo smatrali kako je tip skladbe poput ove odabrane prikladniji u svrhu navedenog cilja istraživanja jer je ukupno upamćivanje moglo u manjoj mjeri biti odraz uvježbanosti u pamćenju različitih verbalnih materijala te više odraz opće sposobnosti pamćenja teksta koja je onda mogla biti potpomognuta uglazbljenošću materijala. Vezano uz period retencije, $u$ ovom istraživanju nije ispitivano pamćenje teksta skladbe nakon umjereno dugih vremenskih intervala (npr. tjedan dana) zbog problema praktične prirode i dugotrajnosti istraživanja, što bi bilo zanimljivo ispitati s obzirom na spomenute rezultate.

Rezultati ovog istraživanja otvaraju mogućnosti za nekoliko budućih istraživanja. Prije svega, potrebno je usporediti strategije upamćivanja i karakteristike materijala koje pomažu pri upamćivanju kod pamćenja uglazbljenog i neuglazbljenog teksta. Zatim je potrebno provjeriti točnost hipoteza o pogrešno percipiranoj visokoj distinktivnosti pamćenja glazbenog materijala, odnosno dolazi li do pogrešne atribucije zbog usporedbe pamćenja uglazbljenog teksta s pamćenjem školskog gradiva. Budućim bi se istraživanjima trebala ispitati i točnost hipoteze o pogrešno percipiranoj visokoj konzistentnosti pamćenja glazbenog materijala. Nadalje, ako je točno da uglazbljenost ima pozitivan utjecaj na pamćenje tijekom umjereno dugih vremenskih perioda, zanimljivo bi bilo precizirati vremensku točku u kojoj se taj pozitivan efekt pojavljuje, kao i vremensku točku u kojoj taj efekt nestaje. Na temelju prethodnih istraživanja (Racette i Peretz, 2007; Rainey i Larsen, 2002) možemo pretpostaviti da taj efekt nestaje u periodu između tjedan dana $i$ nekoliko mjeseci nakon slušanja skladbe.

Hipotezu o smanjenju truda uloženog u upamćivanje također je potrebno ispitati. Važno je napomenuti kako vrijeme koje je sudioniku potrebno za svako ponavljanje nije dobra mjera truda uloženog u pamćenje. Naime, kako je duže vrijeme potrebno i kod boljeg pamćenja zbog većeg broja stihova i kod lošijeg pamćenja zbog težeg dosjećanja stihova, rezultate bi dobivene mjerenjem vremena potrebnog za svako ponavljanje bilo teško interpretirati. Mogućnost je provođenja analize kovarijance upitna zbog statističkih ograničenja (u predistraživanju nije pronađena povezanost između broja bodova i vremena potrebnog za svako ponavljanje, što je uvjet za analizu kovarijance). Podaci bi se o vremenu potrebnom za svako ponavljanje mogli interpretirati jedino ako bi se odvojeno mjerilo vrijeme 
koje sudionik troši na pisanje od vremena koje troši na dosjećanje, što je također nemoguće jer se sudionici nekih stihova dosjećaju tijekom pisanja ostalih stihova. Ostali faktori, poput brzine pisanja također utječu na vrijeme. U ovakvom tipu istraživanja bi uložen trud, unatoč nedostatcima takvih mjera, čini se najprimjerenije bilo mjeriti mjerama samoizvješćivanja, poput skala Likertova tipa.

\section{Zaključak}

U ovom je istraživanju ispitivano utječe li stupanj uglazbljenosti teksta na količinu zapamćenog teksta te variraju li strategije upamćivanja i karakteristike materijala koje pomažu pri upamćivanju ovisno o stupnju uglazbljenosti teksta. Utvrđeno je da stupanj uglazbljenosti teksta ne utječe na broj zapamćenih stihova skladbe ni na čestinu korištenja različitih strategija upamćivanja. No, stupanj uglazbljenosti utječe na čestinu oslanjanja na neke karakteristike materijala koje, prema izjavama sudionika, pomažu pri upamćivanju. Fisherov egzaktni test pokazao je značajnu razliku između triju skupina sudionika u korištenju Glazbe kao karakteristike koje pomaže upamćivanju. Kako je riječ o omnibus-testu, ne može se sa sigurnošću utvrditi između kojih se grupa sudionika pojavljuje značajna razlika u čestini korištenja Glazbe kao pomoći pri upamćivanju, no na osnovi bruto rezultata čini se kako postoji trend da porastom uglazbljenosti teksta raste i broj sudionika koji glazbu koriste kao pomoć pri upamćivanju. Također, u skupini koja je slušala $a$ capella verziju skladbe broj sudionika koji su izjavili da im je u pamćenju pomogla Priroda vokala bio je veći negoli u ostale dvije skupine. Moguće je da ljudi pogrešnim atribucijama stječu dojam da im glazba pomaže u pamćenju, što je potrebno ispitati daljnjim istraživanjima.

\section{Literatura}

Adams, H.F. (1915). A note on the effect of rhythm on memory. Psychological Review, 22(4), 289-298. doi:10.1037/h0075190

Baddeley, A.D. (1968). How does acoustic similarity influence short-termmemory? Quarterly Journal of Experimental Psychology, 20(3), 249-264. doi:10.1080/ 14640746808400159

Barlow, M.C. (1928). A learning curve equation as fitted to learning records. Psychological Bulletin, 35(2), 142-160. doi:10.1037/h0070275

Bower, G.H. i Bolton, L.S. (1969). Why are rhymes easy to learn? Journal of Experimental Psychology, 82(3), 453-461. doi:10.1037/h0028365

Bradshaw, G.L. i Anderson, J.R. (1982). Elaborative encoding as an explanation of levels of processing. Journal of Verbal Learning and VerbalBehavior, 21(2), 165-174. doi:10.1016/s0022-5371(82)90531-x 
Calvert, S.L. i Tart, M. (1993). Song versusverbal forms for very-long-term, long-term and short-term verbatim recall. Journal of Applied Developmental Psychology, 14(2), 245260. doi:10.1016/0193-3973(93)90035-t

Davis, F.C. (1930). The relative reliability of words and nonsense syllables as learning material. Journal of Experimental Psychology, 13(3), 221-234. doi:10.1037/h0071308

Dowling, W.J. (1978). Scale and contour: Two components of a theory of memory for melodies. Psychological Review, 85(4), 341-354. doi:10.1037/0033-295x.85.4.341

Elias, C.S. i Perfetti, C.A. (1973). Encoding task and recognition memory: The importance of semantic encoding. Journal of Experimental Psychology, 99(2), 151-156. doi:10.1037/ h0034644

Epstein, W., Rock, I. i Zuckerman, C.B. (1960). Meaning and familiarity in associative learning. Psychological Monographs, 74.

Everett, W. (2008). The foundations of rock: From "blue suede shoes" to "Suite: Judy Blue Eyes". Oxford: Oxford University Press.

Fallon, A.B., Groves, K. i Tehan, G. (1999). Phonological similarity and trace degradation in the serial recall task: When CAT helps RAT, but not MAN. International Journal of Psychology, 34(5-6), 301-307.

Frith, S., Straw, W. i Street, J. (Ur.) (2001). The Cambridge companion to pop and rock. Cambridge: Cambridge University Press

Gingold, H. i Abravanel, E. (1987). Music as a mnemonic: The effects of good- and badmusic settings on verbatim recall of short passages by young children. Psychomusicology: A Journal of Research in Music Cognition, 7(1), 25-39. doi:10.1037/h0094188

Hewstone, M. i Jaspars, J. (1987). Covariation and causal attribution: A Logical model of the intuitive analysis of variance. Journal of Personality and Social Psychology, 53(4), 663672. doi:10.1037/0022-3514.53.4.663

Kelley, H.H. (1973). The processes of causal attribution. American Psychologist, 28(2), $107-$ 128. doi:10.1037/h0034225

Kilgour, A.R., Jakobson, L.S. i Cuddy, L.L. (2000). Music training and rate of presentation as mediators of text and song recall. Memory \& Cognition, 28(5), 700-710. doi:10.3758/bf03198404

Krueger, W.C.F. (1929). The effect of overlearning on retention. Journal of Experimental Psychology, 12(1), 71-78. doi:10.1037/h0072036

McElhinney, M. i Annett, J.M. (1996). Pattern of efficacy of a musical mnemonic on recall of familiar words over several presentations. Perceptual and Motor Skills, 82(2), 395400. doi:10.2466/pms.1996.82.2.395

Mikumo, M. (1992). Encoding strategies for tonal and atonal melodies. Music Perception: An Interdisciplinatory Journal, 10(1), 73-82. doi:10.2307/40285539 
Paivio, A. (1969). Mental imagery in associative learning and memory. Psychological Review, 76(3), 241-263. doi:10.1037/h0027272

Purnell-Webb, P. i Speelman, C.P. (2008). Effects of music on recall for text. Perceptual and Motor Skills, 106(3), 927-957. doi:10.2466/pms.106.3.927-957

Racette, A. i Peretz, I. (2007). Learning lyrics: To sing or not to sing? Memory \& Cognition, 35(2), 242-253. doi:10.3758/bf03193445

Rainey, D.W. i Larsen, J.D. (2002). The effect of familiar melodies on initial learning and long-term memory for unconnected text. Music Perception: An Interdisciplinary Journal, 20(2), 173-186. doi:10.1525/mp.2002.20.2.173

Rubin, D.C. i Friendly, M. (1986). Predicting which words get recalled: Measures of free recall, availability, goodness, emotionality, and pronunciability for 925 nouns. Memory \& Cognition, 14(1), 79-94. doi: 10.3758/BF03209231

Rubin, D.C. i Wallace, W.T. (1989). Rhyme and reason: Analyses of dual retrieval cues. Journal of Experimental Psychology: Learning, Memory, and Cognition, 15(4), 698709. doi:10.1037/0278-7393.15.4.698

Rundus, D. (1977). Maintenance rehearsal and single-level processing. Journal of Verbal Learning and Verbal Behavior, 16(6), 665-681. doi:10.1016/s0022-5371(77)80026-1

Schulkind, M.D. (2009). Is memory for music special? Annals of the New York Academy of Sciences, 1169, 216-224. doi:10.1111/j.1749-6632.2009.04546.x

Schulkind, M.D., Hennis, L.K. i Rubin, D.C. (1999). Music, emotion, and autobiographical memory: They're playing your song. Memory \& Cognition, 27(6), 948-955. doi:10.3758/bf03201225

Serafine, M.L., Crowder, R.G. i Repp, B.H. (1984). Integration of melody and text in memory for songs. Cognition, 16(3), 285-303. doi:10.1016/0010-0277(84)90031-3

Serafine, M.L., Davidson, J., Crowder, R.G. i Repp, B.H. (1986). On the nature of melody text integration in memory for songs. Journal of Memory and Language, 25(2), 123 135. doi:10.1016/0749-596x(86)90025-2

Shepherd, J., Horn, D., Laing, D., Oliver, P. i Wicke, P. (Ur.). (2003). Continuum encyclopedia of popular music of the world: Volume II: Performance and production. London: Continuum.

Silverman, M.J. (2007). The effect of paired pitch, rhythm, and speech on working memory as measured by sequential digit recall. Journal of Music Therapy, 44(4), 415-427. doi: $10.1093 / \mathrm{jmt} / 44.4 .415$

Stalinski, S.M. i Schellenberg, E.G. (2013). Listeners remember music they like. Journal of Experimental Psychology: Learning, Memory, and Cognition, 39(3), 700-716. doi:10.1037/a0029671

Thomson, R.H. (1930). An experimental study of memory as influenced by feeling tone. Journal of Experimental Psychology, 13(5), 462-468. doi:10.1037/h0074526 
Wallace, W.T. (1994). Memory for music: Effect of melody on recall of text. Journal of Experimental Psychology: Learning, Memory, and Cognition, 20(6), 1471-1485. doi:10.1037/0278-7393.20.6.1471

Wickelgren, W.A. (1972). Trace resistance and the decay of long-term memory. Journal of Mathematical Psychology, 9(4), 418-455. doi:10.1016/0022-2496(72)90015-6

Yalch, R.F. (1991). Memory in a Jingle Jungle: Music as a mnemonic device in communicating advertising slogans. Journal of Applied Psychology, 76(2), 268-275. doi:10.1037/0021-9010.76.2.268

\title{
Influence of the Degree of Musical Accompaniment on Text Recall
}

\begin{abstract}
Introspective findings show that remembering musical material is easier and lasts longer than the remembering other types of material. It is also known that people believe that music is a good mnemonic. However, these assumptions have not been experimentally confirmed. Experiments show that the positive effect of music on memorising is dependent on the conditions of memorising (e.g., memory for a musically accompanied or unaccompanied material is equal if the rate at which material is presented is the same). The effect of the degree of musical accompaniment on memory has rarely been studied. This study aimed at examining whether the degree of musical accompaniment affects the quantity of remembered text. Furthermore, memory strategies and characteristics of the material which might help memory were examined, depending on the degree of musical accompaniment

A sample of 91 participants participated in the study. Participants were divided into three groups, and their task was to listen to a composition and remember as many lyrics as they can. The first group listened to the a capella version, the second group listened to a drum-only composition, and the third group listened to a composition with full musical accompaniment. Participants listened to a composition 6 times and wrote down all the lyrics they could remember after each listening. Demographic data were collected and participants filled out the Questionnaire on the use of strategies.

ANOVA found no differences in the quantity of remembered lyrics between the three experimental groups. Also, no differences in the frequency of various memory strategies used were found. However, Fisher's exact test revealed a trend showing that the number of participants which reported that music helped them remember the lyrics has increased with the degree of musical accompaniment. Also, the number of participants which stated that the nature of vocal helped them remember text declines as the degree of musical accompaniment increases.

The results of this study are in accordance with previous findings which suggest that musical accompaniment does not help in memorising. However, it seems that, regardless of objective indicators, participants have the impression that music helps them remember. This possibility is discussed through Kelley's covariation model of attribution. Two hypotheses are proposed to explain the results: the hypothesis on wrongly perceived high distinctiveness and the hypothesis on wrongly perceived high consistency of memory of music material.
\end{abstract}

Keywords: recall, music, degree of musical accompaniment, mnemonic 


\section{La relación entre la musicalización de la letra y su memorización}

\section{Resumen}

Los hallazgos introspectivos demuestran que las personas memorizan el material musicalizado con más facilidad y a largo plazo, en comparación con otros tipos de material. Además, resulta que las personas consideran que la música es una buena mnemotécnica y que ayuda en el proceso de memorización. Sin embargo, las pruebas experimentales no confirman estas hipótesis. En los experimentos se comprueba que la relación positiva entre la música y la memorización depende de las condiciones de la memorización (p. ej. se memoriza igual la letra musicalizada y aquella no musicalizada si la velocidad de presentarla es la misma). Esta relación está muy poco investigada y por eso representa el objetivo de este trabajo. Además, se ha investigado si las estrategias de memorización cambian dependiendo del grado de musicalización, tanto como si cambian las características del material en el que se basa la memorización dependiendo del grado de musicalización del mismo material.

En la investigación participaron 91 personas. Los participantes fueron divididos en tres grupos y la tarea de cada grupo fue tratar de memorizar la letra de una canción cuanto más posible. El primer grupo escuchó la canción a capella, el segundo grupo una interpretación vocal seguida por la batería y el tercer grupo una interpretación vocal completamente musicalizada. Los participantes escucharon la canción seis veces y después de cada interpretación, apuntaron los versos memorizados. Además, completaron el Cuestionario de las Estrategias Utilizadas.

El análisis de las diferencias no ha determinado ninguna diferencia en cuanto al número de versos memorizados entre los tres grupos de participantes que escucharon el material de diferente grado de musicalización. Tampoco se han determinado diferencias en cuanto a la frecuencia en el uso de diferentes estrategias de memorización. Mientras tanto, a través del Test Exacto de Fisher se ha determinado la tendencia de aumento de número de participantes que afirman que la música les ayuda en la memorización si la letra es más musicalizada. Además, con el aumento del grado de musicalización del material disminuye el número de personas que afirman notar la ayuda del índole de la vocal en la memorización del material.

Resultados de esta investigación corresponden a los hallazgos anteriores que sugieren que la musicalización objetivamente no ayuda a la memorización. Pero, parece que independientemente de los hechos objetivos, los participantes tienen la impresión de que la música ayuda a la memorización. Esta posibilidad se discute a través del modelo de covariación de Kelley. Se han sugerido dos hipótesis para explicar los resultados obtenidos: la hipótesis sobre la distinción alta percibida erróneamente de memorizar el material musical y la hipótesis sobre la consistencia alta percibida erróneamente de memorizar el material musical.

Palabras claves: recuerdo, música, grado de musicalización, mnemotécnica

Primljeno: 30.03.2016. 


\section{Prilog A}

\section{Detaljne pismene upute o načinu bodovanja koje su primili ispravljači}

U istraživanju "Utjecaj stupnja uglazbljenosti teksta na pamćenje" zavisna je varijabla pamćenje teksta pjesme. Ta je zavisna varijabla operacionalizirana kao broj točno napisanih stihova. Zbog nemogućnosti uzimanja $u$ obzir određenih semantičkih elemenata ako bi se mjerio samo broj točnih riječi, a ne stihova, zavisna je varijabla operacionalizirana kao broj točnih stihova, a ne riječi.

Za svaki točno napisan stih sudionik treba dobiti jedan bod. Ako nije napisan cijeli stih, svaki ispravljač treba zasebno odlučiti je li napisani dio stiha dovoljno dugačak da bi sudionik za njega dobio jedan bod, pola boda ili nula bodova.

Ako je sudionik poredao riječi drukčije nego u originalu pjesme, svaki ispravljač treba zasebno donijeti odluku hoće li ispitaniku priznati jedan bod, pola boda ili nula bodova, ovisno o tome kako taj poredak utječe na značenje stiha. Poredak stihova ili dijelova stihova se ne uzima u obzir (npr. ako je sudionik stih s kraja pjesme napisao na početku, a stih je u potpunosti točan, za njega treba dobiti jedan bod).

Ako je sudionik umjesto riječi ili izraza koji se pojavljuju u originalu pjesme rabio neke druge riječi ili izraze istog ili sličnog značenja, svaki ispravljač treba zasebno donijeti odluku hoće li ispitaniku priznati jedan bod, pola boda ili nula bodova, ovisno o tome kako korištenje tih riječi utječe na značenje stiha.

Ako je sudionik napisao riječi ili izraze koji nemaju isto ili slično značenje, ali slično zvuče riječima ili izrazima koji se pojavljuju u originalu pjesme, može se pretpostaviti da je ispitanik riječi krivo čuo, a ne krivo zapamtio te bi mu stoga te riječi trebalo priznati. Svaki ispravljač treba zasebno donijeti odluku je li ispitanik riječi krivo čuo ili krivo zapamtio te mu ovisno o tome dodijeliti jedan bod, pola boda ili nula bodova.

Ako je sudionik više puta ponovio isti stih ili dio stiha, bodovi mu se daju samo za jedan od tih stihova ili dijelova stiha.

Ako se u nekom napisanom stihu pojavljuje kombinacija svih ili nekih od ovih grešaka, svaki ispravljač treba zasebno donijeti odluku o tome koliko će bodova dati sudioniku uzimajući u obzir sve navedene faktore.

Četrnaesti stih ("Neću troje") boduje se s pola boda.

Budite oprezni jer pojedini sudionici znaju više stihova (npr. 2) napisati u jednom redu (ako su stihove točno napisali, to im se priznaje kao više (npr. 2) bodova) ili jedan stih u više redova (ako su sve točno napisali, to im se priznaje kao jedan bod).

Individualne se riječi ne boduju. Interpunkcijski se znakovi ne uzimaju u obzir.

Najveći je mogući broj bodova 16.5 . 
Prilog B

Tekst skladbe "Ako već brineš" s pripadajućim punim bodovnim vrijednostima pojedinih stihova, zbrojem tih vrijednosti (maksimalnim brojem bodova koji je sudionik mogao postići u jednom ponavljanju) i polovičnim bodovnim vrijednostima pojedinih stihova navedenim u zagradama:

Preko volje, dan je dosadan

Zovu dolje doma u podzemlje

Hajka pasa, rulja zlikovaca

Ravna crta, bez emocija

Tirani, barbari, pitomi pokosili divlje

Pitaj svoja pitanja i slušaj im laži

Budi moj razum, budi moj saveznik

Bez dobre volje ja nisam dobar lik

Za svakoga ponešto, za nekoga sve

Ovdje po mjeri šivam karaktere

Nova stvorenja riču na lavove

Dok mačke nema miševi kolo vode

Nas je dvoje, ne želim tu stat'

Neću troje

Oči sanjara bez dara

$K$ cilju podvita repa

Hranim i oblačim makar mi smeta

$\begin{array}{cc}1 & (0.5) \\ 1 & (0.5) \\ 1 & (0.5) \\ 1 & (0.5) \\ 1 & (0.5) \\ 1 & (0.5) \\ 1 & (0.5) \\ 1 & (0.5) \\ 1 & (0.5) \\ 1 & (0.5) \\ 1 & (0.5) \\ 1 & (0.5) \\ 1 & (0.5) \\ 0.5 & \\ 1 & (0.5) \\ 1 & (0.5) \\ 1 & (0.5) \\ \Sigma=16.5 & \end{array}$

